\title{
The Importance of Culture in Translation: Should Culture be Translated?
}

\author{
Ahmad Al-Hassan \\ Petra University English Department \\ Amman, Jordan \\ PO box 940937 \\ Amman 11194 \\ Telephone+962795565486 E-mail: dral_hassan@hotmail.com
}

Received: 29-10- 2012

doi:10.7575/aiac.ijalel.v.2n.2p.96
Accepted: 05-01- 2013

Published: 01-03- 2013

URL: http://dx.doi.org/10.7575/aiac.ijalel.v.2n.2p.96

\begin{abstract}
Recognizing the importance of culture in translation, this article presents a descriptive study of translation of literary texts from English into Arabic. Using the data taken from works of Shakespeare and others which were translated by eminent translators, it first describes the study background, research contexts and procedures and problems. It then addresses some research questions on: (1) Will the translation be accepted by the new community of readers; 2) Is the relation between culture and translation important? It is worth noting that this study is significant for translators and readers of the target language, which is Arabic in this case. This has been substantiated by surveying the interests in cultural aspects of translation as early as the 19th Century. Thus translations do not only include lexical content and syntax, but also ideologies, values and ways of life in a given culture, which form translating problems. Therefore, translators have to know the audience.
\end{abstract}

Keywords: culture, translation, semiotics, familiarization, foreignization, source

\section{Introduction}

The domain of translation studies has expanded beyond the limits of language to include the cultures of the source and the target languages. Translation theorists, however, showed interest in cultural aspects of translation as early as the nineteenth century, probably earlier. Thus in 1811, the German philosopher, Goethe wrote (cited in Robinson, 1997)

There are two maxims for translation, the one requires that the foreign author be brought over to us so that we can look upon him as our own; the other that we cross over to the foreign and find ourselves inside its circumstances, its modes of speech, its uniqueness. (p. 222)

Two years later the German translation theorist Schleiermacher (cited in Robinson 1997) asked: But what paths are open to the true translator? He answers:

I believe there are only two, the translator either (1) disturbs the writer as little as possible and moves to the reader in his direction, or (2) disturbs the reader as little as possible and moves the writer in his direction. The two approaches are so absolutely different that no mixture of the two is to be trusted, as that would increase the likelihood that the writer and the reader would miss each other entirely; it is important, therefore, that one or the other be followed as closely as possible. (p. 229)

The first method, the reader-to-the writer, and the second method, the writer-to-the reader, have been termed foreignization and familiarization (or domestication) respectively.

Culture may be defined as the whole way of life, which consists of the mores of a given society; their religion, values, traditions, habits, educational systems, family and social structures, political and governmental hierarchies, and use of advanced technology (Geertz, 1975, Lado, 1968). Halliday (1989) adopted a semantic definition when he says that culture is "a set of semiotic systems, a set of systems of meaning, all of which interrelate" (p. 4). Thus culture embraces all aspects of shared life in a community and these "ways; might be highly revered by the people who share them. Different cultures have different views on what constitutes moral and immoral behavior. Values tend to be absolute and immutable. And this is in itself has a direct influence on culture. As a specific example, polygamy is immoral in Western culture, whereas in Islamic culture it is considered immoral if one objects to it. Accordingly, Arab culture may reasonably be presumed to be different from the Anglo-American culture. Certainly, many people perceive it as very different. As a deeply religious society wherein God's word is an absolute, there is none of the liberalism demonstrated in Western culture, where values are apparently more relative as seen above.

Accordingly, translation involves at least two languages and two cultures (Toury1978); and since language is an integral part of culture, the question that may be asked here is: Can translation be achieved in isolation of culture? As Pym (2000) states: 
The simple fact of translation presupposes contact between at least two cultures. To look at translation is immediately to be engaged in issues of how cultures interrelate. (p. 2)

It is to be noted that I used above the vague verb 'involve' because in the case of language this normally means replacing one language by another. With regard to culture, things are not so clear; 'involve' might mean (a) preserving the original culture (foreignization), (b) substituting the source culture for the target culture (familiarization) and (c) mixing both (a) and (b). Strictly speaking, only (b) is culture translation. However, the most practiced approach is (c), as the present article will illustrate. To separate (a) and (b) completely, as Schleiermacher (cited in Robinson, 1997) recommends, is often not feasible. Every translation is more or less a mixture of the two processes: foreignization and familiarization.

My main concern here is literary texts. However, two other types of texts should be mentioned here, as they are closely related to translation and culture. First, scientific texts, which may be said to belong to what is termed 'universal culture'; the translator here works within a neutral culture; he/she is most concerned with 'content': conveying facts and ideas, and is least interested in the cultural context of the text, since this context is assumed to be similar to source text and the target text. In this type of texts it is safe to say that very little cultural translation takes place when a text is transferred into another language.

Advertisements, the second type, belong to the opposite extreme. They are culture specific, and normally cannot be translated. Usually they are rewritten in the new language. Advertisements are couched in their culture so deeply that they fail if they are transplanted into a foreign culture (cf. De Mooij, 2004).

The rest of this article will discuss translation and culture in literary texts. The main points of the argument will be illustrated by authentic examples.

\section{The relation between translation and culture}

In the early stages of translation theory, translation was defined as replacing a text in one language by another in a different language, with the two texts having approximately the same meaning. The main emphasis was on the linguistic and the semantic aspects of translation, whether in the process of the product. The meaning in translation has always been problematic; what meaning is intended? Is it semantic or pragmatic or social? Finally all these types of meaning were thought relevant, and have been resumed under 'cultural aspects of translation. Nowadays translation is rarely envisaged without one taking into account the source culture and the target culture.

Can culture be translated? Can a text be translated in isolation of its culture? It is a linguistic fact recognized by every scholar that language is interwoven with the threads of culture, and that it is difficult, probably impossible, to separate the two. If this is true, then every act of translation involves both language and culture when 'market', for instance, is rendered into Arabic as 'suq', the two words refer to two different things in different cultures, two different activities of buying and selling. If the reader of translation coming across 'suq' conceptualizes 'the oriental market', then the source culture has been replaced by the target culture and we are in the process of familiarization. If, on the other hand, the new reader, through his efforts or those of the translator, conceptualizes 'an English market', then we are dealing with the process of foreignization. This is a simple example, but it is adequate to clarify the relation between culture and translation. It is clear from this example that the new reader plays an important role in this relation. A well- educated reader reacts differently to a translation from a less educated reader. Great works of translation do not only transform texts, but also the mind of the reader in the target language. This is the most effective type of translation, of which we read in the books of history, taking place in certain periods of intellectual transformation like the one which took place at the time of the Abbasid period and reached its peak in the reign of the Caliph Al-Ma'mun. Through translation, Arab scholars mastered the learning of the Greeks, the Persians and the Indians; they assimilated the new ideas which became part of their own culture. The same process, or something similar, took place at the beginning of the Renaissance in Europe, when, through translating the learning of the ancients was rediscovered, often via the writings of the Arabs. All these great translations affected greatly the Arab and European cultures.

A translator is a cultural mediator, who may move from the source culture to the target culture, choosing as much as he/she thinks appropriate to serve the aim of the translation. . One basic purpose why we translate from language A into langue $\mathrm{B}$ is to enrich linguistically and culturally language B. In this case the translator aims at preserving as much as possible the source culture. He/she translates the content and the style of the source text and introduces these into the target text. Gradually these foreign elements are integrated into the target language and culture and become part of the new environment. However, there is always the danger of rejection, similar to that which takes place in the medical transplant of organs in the new body. Integration or rejection awaits every work of translation. Obviously, our interest lies in integration, which is surely the characteristic of a successful translation.

\section{Translation and Integration}

\subsection{Familiazation}

The translator moves cautiously between the two extremes of foreignization and familiarization and gropes for a happy medium, which will guarantee that his/her translation will be accepted by the new community of readers. Leaning too much towards the foreign elements in a translation might alienate the new reader, who may find it difficult to understand the new text. This and other factors will not encourage integration. In translating Hamlet, for instance, into Arabic, the translator may think that the reader will find certain aspects of life in Elizabethan England difficult to 
understand or accept; thus the translator moves gently towards bringing the author towards the new reader as in the following examples:

(1) Osrick. How is't Laertes?

Laertes: Why, as a woodcock to mine own springe. Osrick;

I am justly kill'd with mine own treachery.

(Hamlet, Act 5, Scene 2. 315-307)

$$
\begin{aligned}
& \text { اوسرك : كيف أنت يالورتيس! }
\end{aligned}
$$

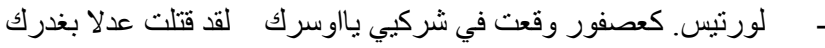

(Translated by Jabra I. Jabra)

The unfamiliar bird 'woodcock' is replaced by ، عصفور (sparrow), which is easier to comprehend by the Arab reader.

(2) Hamlet: Why, what should be the fear?

I do not set my life at a pin's fee;

(Hamlet, Act I, Scene 4. 67)

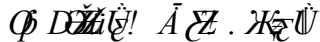

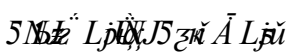

(Translated by Jabra I. Jabra)

Here again an unfamiliar expression 'a pin's fee' is substituted for the familiar one ' بفلسين small coin). Probably the translator has pushed the process of familiarization too far in this example, see section $3 \mathrm{~B}$.

(3) King: Ay me! Says one, o Jove! The other cries.

(Love's Labour's lost IV.3. 139)

$$
\text { الملك. فان قال أحدكما "و اهالي" صباح الخير " لطفك ياله" }
$$

(Translated by Lewis Iwad)

In this example from Love's Labour Lost, the pagan god 'Jove' is replace by اله

(God), the monotheist symbol, which the translator believes is more acceptable in an Islamic context. In the next example the translator uses over lexicalization (two words for one, to bring the original style nearer to the style of the target text...

(4) Polonius: I mean the matter that you read, my Lord.

Hamlet: Slanders, sir.

(Hamlet, II, Scene 2, 192)

$$
\text { بولو هاملت. قدح وذم ـ اعني الكلمات التي تقر أها ، يامو لاي }
$$

(Translated by Jabra I. Jabra)

Overlexicalizagtion is also found in the following example from Hamlet.

(5) Marcellus: Something is rotten in the state of Denmark.)

(Hamlet, Act I. Scene 4, 90)

(Translated by Jabra I. Jaba)

\subsection{Limits of familiarization}

Too much movement towards the new reader deforms the original text and destroys the main aim of translationenriching the target culture. No one will approve turning Hamlet, through familiarization, from a prince of Denmark to a prince of Arabia. The main foreign elements of the source text should be preserved; Hamlet should speak and behave as a Danish prince; the society portrayed by the original author must remain essentially the same. The translator has to be careful not to make the characters in the translation too 'native', and behave exactly as the members of the target culture do. In the following example the translator has probably used too much familiarization and his characters have gone native.

(6) Armado: Warble, child; make passionate my sense of hearing. Moth. Con. Colinol.

(Love's Labour Lost, Act III, Scene I, 1-2)

$$
\text { مث. جاء الهوى ياعودي ثمن ياغلام. واملأ مسامعي بسحر الغر ام. }
$$

(Translated by Lewis Iwad) 
Here Moth speaks like a native speaker, or even better; his speech is in rhyme. He is too fluent in Arabic to represent satisfactorily the foreign character. In the next example, the character's speech is in the Quar'anic style, which is unusual even for an ordinary native speaker of Arabic.

(7) Tabot: Heavens, can you suffer hell so to prevail?

(King Henry VI, Part I, Act 1, Scene 5, 9)

$$
\text { ـالبوت. رباه ـ أترضى أن تسود زبانية الجحيد؟ }
$$

(Translated by Muhammed Fathi)

Substitution of money, measure, food is a common way of crossing too deep into the target culture, as in the following example from King Lear.

(8) Lear: Give me one ounce of civet, good apothecary, to sweeten my imagination. (King Lear, Act IV. Scene 6.130)

$$
\text { ـ لير ـ أيها الصيدلي الكريم ـ أعطن در هما من عطر الزباء اطيب به خيالي }
$$

(Translated by Jabra I. Jabra)

Speaking of food in English -Finnish translation, Ritva Lappihalme (1997, 118) writes:

In most cases, rendering haggie by kalakuhko (an East-Finnish specialty made of rye flour and fish) will shatter the 'illusion'.

This is what takes place in Example 2 above the severity of a punishment, and thus crosses too far into the target culture., where 'pin's fee' is replaced by a unit of the target language currency, . فلسين In the next example the translator brings in (metaphorically) a native dish, 'kebab' to emphasize the severity of a punishment, and thus crosses too far into the target culture.

(9) Kent: Draw, you rogue! or I'll so carbonado your shanks:--draw, you rascal!

(King Lear, Act2, Scene 2, .35)

$$
\text { - كنت: سيفك يالئيم ، والا جعلت كبابا من كاحليك. جرد سيفك يانزل. }
$$

(Translated by Jabra I. Jabra)

Probably a neutral expression would have been more appropriate to keep Kent within the limits of the source culture, without crossing over and becoming a true Arab fond of 'Kebab'; suggested translated:

$$
\text { - - - كنت: سيفك يالئيم. و الا حطمت كاحليك، جرد سيفك يانزل }
$$

In example 10, Kent is so much immersed in Arabic culture that he can quote the pre-Islamic poet, Zuhair.

(10) Kent. (to Oswald) Come, sir, arise, away! I'll teach you differences:

away, away! If you will measure you Iubber's length again, tarry;

but away! Go to: Have you wisdom? so.

(Pushes Oswald out)

(King Leer, Act I. Scene 4. 88-92)

$$
\begin{aligned}
& \text { ـ كنت. ياسيد. انهض ، انصرف ! سأعلمك الفروق بين الناس، انصرف! } \\
& \text { إن كنت تبغي قياس الطول في شحمك ثانية، فابق في مكانك ولكن انصرف إن اذهب ـ ـ أما عندك من عقل ؟ (يخرج ازولد) }
\end{aligned}
$$

(Translated by Jabra I. Jabra)

The expression الى حيث القت meaning in this context, 'to hell' comes from the pre-Islamic

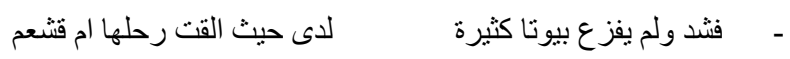

In the Arabic example Kent has lost his main English characteristics.

It is to be noted that even replacing source text poetry by target language poetry will not be successful; it will destroy the illusion of the source text (cf. Leppihalme, 1997, p. 118). Leppihalme (1997) warns against substitution of proper names in fiction: 
There is a need for caution when assessing whether target cultural replacements can be used for names in fiction, as such names are implausible if uttered by characters that are presented as living in the source culture. Even substituting a TL name that has won some fame internationally for an unfamiliar SL name used by the author needs to be weighed with great care. ( p.111).

In the following example, the illusion created by the fool's speech is ruined through substituting the target culture name "حنونة"for the source culture name 'Jug'.

(11) Fool: May not an ass know when the cart draws the horse?

Whoop, Jug, I love thee!

(King Lear, Act I, Scene 4, 220-221)

$$
\text { بهلول. ألا يعرف الحمار متى تجر العربة الحصان ؟ أحبك واله ياحنونة }
$$

(Translated by Jabra I. Jabra)

\section{Conclusion}

Culture should be considered a vital component of translation. Lack of adequate knowledge of culture causes difficulty in comprehending a text full of cultural references as shown above. Thus the main aim of translation is to enrich the target language, both linguistically and culturally. Every language is couched in its culture and it is doubtful if a language can be replaced by another without some of the source culture being carried over during the process of translation. However, a translator acts as a mediator between the source culture and the target culture; he/she systematizes the process of cross-cultural translation. There are two main approaches to perform this task: either the author is brought to the reader (familiarization) or the reader is brought to the author (foreignization). The latter process promotes the enrichment of the target language.

If the principal aim of translation is, as stated above, to enrich the target language and culture, then obviously a translator would mostly concern himself/herself with the second approach. There are, however, limits to the two approaches; a translation which carries with it too many foreign elements may never become integrated into the new culture; and integration is the surest proof of a successful translation. Rejection means that a translation has failed.

The translator may substitute familiar elements from the target language for those aspects of the source language which he/she thinks might be incomprehensible or unacceptable to the new reader. However, the risk here is too much familiarization; there are red lines which should not be crossed. These include replacing proper names by names from the target culture, using target culture proverbs and maxims, quoting verses; all these may encroach too far into the target culture and destroy the illusion created by the source text. Therefore the task of the translator as a mediator is to find a happy medium between the two approaches of familiarization and foreignization. If he/she finds this golden means, he/she will have achieved his/her task successfully.

\section{References}

Catford, J.C. (1965). A Linguistic theory of translation. Oxford: Oxford University Press.

De Mooij, M. (2000). Translating advertising. The Translator 10 (2), 179-198.

Eco, U. (1990). Introduction. In Lotman (Ed.). Experiences in translation 7-13 Toronto: University of Toronto Press. Geertz, C. (1979). The interpretation of culture :Selected essays. London: Fontana Press.

Halliday, M., \& Hassan, R. (1989). Language, context, and text: Aspects of language in a social semiotic perspectives. London: Edward Arnold.

Jabra, I. J. (1986). William Shakespeare: The great tragedies. Beirut: Arab Studies Establishment.

Jakobson, R. (1971). On linguistic aspects of translation. In Jakobson, R. (Ed). Selected Writings 2. Word and Language. The Hague:Mouton, pp.260-266.

Lado, R. (1968). Linguistics across cultures: Applied linguistics for Language teachers. Ann Arbor: The University of Michigan Press.

Leppinhalme, R. (1997). Culture bumps: An empirical approach to the translation of allusions. Clevendon: Multilingual Matters Ltd.

Lotman, Y. M. (1990). Universe of the mind: A semiotic theory of culture. London: I. B. Tauris.

OIk, H. (2003). Cultural knowledge in translation. ELT Journal 57(2), 167-178.

Pym, A. (2000). Negotiating the frontier. Manchester: St Jerome Publishing

Robinson, D. (1997). Western translation theory. Manchester: St Jerome Publishing.

Shakespeare, W. (2001). The complete works of Shakespeare. New Lanark (Scotland): David Dale House.

Toury, E. (1995). The nature and role of norms in translation. London: Routledge. 